\title{
Access to housing and direct housing subsidies: some Latin American experiences
}

\section{Gerardo M. Gonzales Arrieta}

Resident Representative and Technical Manager, Inter-American Housing Union, Lima, Peru.
After a brief introduction, this article analyses in its second section the roles that the public and private sectors should play under a housing and housing finance policy in which the function of the State is to facilitate the development of the sector while occupying a subsidiary position with respect to private enterprise. It examines the role of direct housing subsidies within such a policy, as a means of creating effective demand for the supply of housing generated by the private sector on market terms, with special attention to the attributes of such subsidies, and it highlights the catalytic role that such a system can play in promoting saving. Section III summarizes the Latin American experience with respect to direct housing subsidy schemes, describes their main features, advantages and limitations, and details the reforms made or proposed, especially in the programmes with the longest history. Finally, section IV sets forth the main lessons to be learned from the Latin American experience, with special emphasis on the conditions and characteristics which have helped in the successful application of these schemes. 


\section{Introduction}

In Latin America and the Caribbean, the quantitative housing deficit -defined as the difference between the number of households and the number of permanent dwellings-amounted in 1995 to 28 million units, while the qualitative deficit -defined as the number of permanent dwellings which are not satisfactory because they lack certain services- came to nearly 26 million of the existing dwellings (ECLAC, 1995). Since the region has some 118 million households, this means that one out of every four Latin American households does not have a dwelling, and if we add to this figure the number of housing units which require some type of rehabilitation, we see that almost half the households in the region are living in unsatisfactory conditions.

This statistical finding highlights not only the magnitude of the housing deficit, which affects all the countries of the region, but also the ineffectiveness of the housing and housing finance policies applied in the past. Furthermore, this heavy housing deficit is concentrated to a large extent in the lowestincome segment of the population, which, although it represents a significant potential demand, has no real possibilities of achieving a suitable housing solution, mainly because of their difficulty in gaining access to finance on appropriate terms due to their lack of sufficient purchasing power, their inability to provide satisfactory collateral for mortgage loans, and their impossibility of attesting to a stable income.

In order to improve the access of the lowestincome sectors to housing, it is necessary to make innovations in the finance policies and instruments in force in this field. This article explores ways of helping to give such sectors suitable purchasing power: that is, creating an effective demand for housing among them, and makes a conceptual and comparative analysis of the Latin American experience in the application of direct housing subsidies (hereafter "DHS") for the lowest-income sectors.

\section{II}

\section{The economic rationale of direct housing subsidies}

\section{Housing policy and the roles of the public and private sectors 1}

The housing and housing finance policies applied in the past in Latin America were marked by predominant State intervention, with only very limited participation by the formal private sector. Under such policies, the State over-regulated the operation of the markets and agents involved -by establishing ceilings for the interest rates charged by housing finance systems, for example- and played a direct role in building and financing dwellings, usually by offering

\footnotetext{
${ }^{1}$ For a more detailed analysis of these matters, see Gonzales Arrieta (1995).
}

loans at subsidized interest rates or subsidizing the prices of the dwellings.

The results were thoroughly counter-productive, as is clearly reflected in the enormous housing deficits accumulated in the region. On the one hand, these housing construction and finance schemes did not meet the aspirations of private housing builders and financial intermediaries in terms of rates of profit. On the other hand, the active role played by the State as a builder of houses bureaucratically defined the characteristics and prices of the latter and the arrangements for allocating them, thus eliminating the functioning of the market mechanisms for the range of dwellings supposedly intended for the lowest-income sectors and thereby driving away private builders. 
Such policies also meant that the credit intended for the building and acquisition of dwellings was insufficient to cover the needs of the region (Zawadzki, 1993, p. 33). In addition, there were the unsuitable terms of access for people of low purchasing power. Together, these factors limited the size and stability of effective demand for housing and mortgage loans. As a result, private builders and financial intermediaries concentrated on serving the demand of the higher-income sectors, giving rise to a doubly perverse effect: on the one hand, the reduction of formal markets and growing inhibition of private investment in the housing sector, and on the other, the increasing prevalence of informal forms of housing construction and finance, which now mobilize a considerable volume of resources in the region (ECLAC, 1996, p. 119).

In some Latin American countries, housing and housing finance policies have registered substantial results, with annual housing production exceeding the new demand generated each year by natural population growth and the formation of new households. These countries have thus begun to reduce the accumulated housing deficit.

The housing and housing finance policy models behind such results have as their common denominator a clear political will to apply a market-based sectoral development model which is compatible with the general economic and social development scheme and is of an integral nature: i.e., provided with the instruments and resources needed to cover the housing requirements of all income-levels.

Such a model recognizes that the State alone is incapable of solving the housing deficit, so that State action must be such as to stimulate private investment. This recognition of the complementary nature of the efforts needed calls for fundamental innovations in public policy, in the instruments applied and the institutional schemes adopted. The traditional role of the State is replaced by the role of a facilitator, designed to provide incentives in terms of the recovery of costs, profit levels and stability so that the housing sector can compete with the other sectors of the economy and private investment can play a major role in housing construction and finance.

The foregoing is based on the assumption that dealing with housing needs is primarily an economic operation that has repercussions on social welfare policy. The multiplier effects of the housing sector on economic activity and employment are just as important as those of other economic sectors, if not more so: every dollar invested in housing generates a further two dollars of economic activity in other sectors, and every additional job in housing construction gives rise to two others in related activities (Mayo and Angel, 1993, p. 34).

The prevalence of conditions of profitability and competitiveness in the real estate and housing finance markets makes it possible, firstly, for the private sector to view the housing construction industry as a business option capable of competing on an equal footing with other sectors of the economy; secondly, for the savings mobilized to the housing sector to obtain positive real levels of profitability; thirdly, for mortgage loans to be recovered in real terms, thus making long-term housing finance a sustainable venture, and fourthly, for financial intermediaries to find a profitable business option in housing finance too.

However, while this model recognizes that private investment in the housing sector will only be viable if market conditions apply in the construction and financing of dwellings, it also has to be admitted that the market mechanisms do not give access to housing to those sectors of the population which do not have sufficient purchasing and payment capacity. The State must therefore also assume a subsidiary role designed to ensure equality of opportunities so that all families, whatever their economic position, will have the possibility of solving their housing problems through the market and obtaining a housing solution in keeping with their own efforts and economic possibilities. This is the context for the use of direct housing subsidies ("DHS") which, in conjunction with the efforts of the families themselves and mortgage loans on market terms, will serve to make up the capacity for the purchase of dwellings built by the private sector for the lowest-income sectors.

\section{Creation of effective demand for housing through direct housing subsidies}

In general terms, DHS are an explicit, once-only, non-repayable contribution given by the State to families that comply with certain established requirements in order to provide them with a purchasing power greater than that afforded by their own income. It is thus a demand subsidy, not a subsidy for supply.

The insufficient purchasing power of broad sectors of the population prevents the enormous poten- 
tial demand which exists from being turned into effective demand which would stimulate investment and private housing supply. The creation of purchasing power in the poorest sectors would therefore lay the foundations for more sustained growth of activity in the housing sector.

Numerous favourable effects can be expected from DHS (Domínguez, 1994b). Thus, they expand the potential real estate market by creating effective capacity for the purchase of private housing supply and at the same time reduce the risks of housing construction, since if private builders can be sure that there will be demand backed up by purchasing power, they will likewise be sure they can sell their houses and the housing supply will be more stable in the medium term: in a climate of free competition this will lead to an improvement in the quality and a reduction in the price of dwellings. DHS also stimulate an increase in the potential market of persons seeking mortgage loans, since by reducing the amount of indebtedness needed to make up the price of a dwelling they mean that, without requiring an increase in their income, recipient families will become eligible for mortgage loans in keeping with their payment capacity. Such subsidies also give rise to a better-quality loan portfolio, since the debtors are assuming obligations that it will be easier for them to pay, while the coverage of the mortgage guarantee will provide a surplus over the debt (equivalent to the amount of the subsidy) which will be greater than the average for the portfolio.

DHS also represent the abolition of the traditional paternalistic attitude taken by the State when dealing with the neediest groups, replacing it with an approach that stimulates and complements the efforts of the families themselves, on the basis of objective and impersonal procedures. They thus strengthen the links between citizens and the State, exploit the advantages of the market economy, and allow beneficiaries to choose the solution best fitting their needs.

By turning the potential demand for housing into effective demand and furthering the functioning of the market economy, DHS stimulate a bigger supply of dwellings and of housing finance, which can facilitate the access of the population sectors with the least resources and make an effective contribution to reducing the housing deficit. These subsidies, which in the final analysis are a contribution by the State that forms part of the growing transfer to the private sector of the leading role in housing finance, have thus shown themselves to be a much more effective means of State intervention.

Why are DHS to be preferred as a means of dealing with the housing needs of the poorest sectors? Firstly, such subsidies are more equitable, since they make it possible to target the efforts more precisely on the population it is desired to benefit, and they are also progressive, because the lower the cost of the dwelling, the higher the corresponding subsidy. In contrast, indirect subsidies through the interest rates on housing loans are highly regressive, because in the absence of a system of allocating loans by prices, the mechanism that prevails is the rationing of the available resources: in this context, those who have most access to the available finance are usually the sectors with most influence or the greatest payment capacity. Such an indirect subsidy is also very inequitable: not only does it not reach the people who need it most, but also those who obtain most credit automatically obtain a bigger contribution from the State.

A second argument in favour of DHS is their greater efficiency. Interest rate subsidies distort the operation of housing finance systems because they do not ensure that the resources loaned will be recovered in real terms, thus leading to the decapitalization of the financial intermediaries and causing housing finance to diminish or disappear. In contrast, DHS are complementary to mortgage loans on market terms and do not displace them: the counterpart of direct housing subsidies should be a loan operation on those terms. Consequently, DHS are perfectly compatible with a housing finance system with positive real interest rates on both savings and loans.

The inefficiency of interest rate subsidies is also reflected in the fact that the State is unable to measure the amount of resources granted in the form of subsidies in a clear and transparent manner and, still worse, the beneficiaries do not have a full perception of the benefits they are receiving. In contrast, DHS can not only be measured precisely in order to determine the amount of fiscal expenditure involved but also -by stimulating family efforts as a requirement for becoming eligible for the subsidy- they give beneficiaries a real awareness of the benefits they receive.

Another argument in favour of DHS is that they involve a smaller administrative burden for the State and hence also a greater saving of fiscal resources. In this type of subsidy, the State's activities are limited to laying down the corresponding regulations, invit- 
ing applications, processing and selecting the applications received, and paying out the subsidies where appropriate. It does not take on long-term administrative commitments, as it does in the case of housing loans at subsidized interest rates. In this latter case, the administrative costs of recovering a loan portfolio which has deteriorated in real terms over time represent a growing burden with respect to the value recovered. It may be noted that the efficiency and efficacy of public spending made possible by the application of a system such as DHS will strengthen the amount set aside for this purpose each year in the public budget. Moreover, if DHS make possible a higher level of activity in the housing and related sectors, the State will be able to recover part or all of its outlays in this respect through the taxes generated by this greater activity.

In short, it may be categorically asserted that DHS are in no way incompatible with the market economy model, since this is an accurately targeted (non-discriminatory) system of finance which makes it possible to effectively reach the population that it is desired to benefit; it is a transparent and accurately measurable (non-hidden) system, both for the State (which knows who it is benefitting, and by how much) and for the beneficiaries (who know how much they are receiving); it does not give rise to distortions in the financial system, as subsidized interest rates do; and it does not displace the private sector from the housing market but, on the contrary, attracts it by turning potential housing demand into effective demand.

\section{The importance of prior saving and its links with direct housing subsidies}

Housing is perhaps the most important durable physical asset of most families, and its price is several times their annual income. The acquisition of a dwelling is normally only feasible through a long-term loan. This purchase is an important incentive for the family to save, postponing present consumption for the benefit of future consumption. In the developed countries, family savings deposited in formal financial institutions are an important source of funds for housing loans (AID, 1987). DHS can serve as an important catalyst for the formation of family savings channeled through the formal financial system.

DHS seeks to stimulate families to make an effort to save in order to gain access to a dwelling, and the typical expression of this effort should be the methodical accumulation of prior savings to supplement the direct subsidy and, when applicable, long-term mortgage loans.

No matter how small it is, prior saving is perhaps the most powerful basis for establishing a transparent and objective system of ranking applicants for DHS, which should be designed to reward the amount saved and the duration, permanence and methodical nature of the prior saving process. Furthermore, the prior saving requirement is a much easier and less costly criterion to manage and control than, for example, one based on income level. Naturally, the prior saving required for requesting and obtaining a DHS must be in keeping with the family income level, the price of the desired dwelling and the number of dependants, among other factors, in order to ensure that State aid goes primarily to the families with the lowest income. It is known from experience that the effort made by families wishing to receive a DHS should not necessarily be expressed in terms of monetary saving. It may also be useful, especially in the case of the lowest-income strata, to accept contributions in kind (such as land, materials or labour). The important thing is to get across the idea that DHS is a reward for family effort, not just a handout.

The available data also show that DHS have served to stimulate the formation of saving for housing which is channelled through the formal financial system (Domínguez, 1994a). In order for this to take place, there must be a favourable macroeconomic climate and the saving must have a positive yield in real terms over time. In inflationary situations like those which have prevailed in the recent past, housing savings in money, deposited in financial systems, have tended to be replaced by housing savings in the form of the acquisition of building sites and materials, which better fulfilled the role of a value refuge over time. Savings in the financial system must be assets which are both sufficiently liquid (subject of course to certain restrictions, in view of their methodical and contractual nature) and also secure. This latter requirement may be strengthened through State guarantees, especially for small savings, and also through the solidity afforded by a suitably regulated and supervised financial system.

In conclusion, the acquisition of a dwelling is usually the result of a private decision and reflects a long-term effort based mainly on family saving. This gives the family a leading role in the solution of 
housing problems. Since many sectors of the population are unable to gain access to a dwelling solely on the basis of their family savings and their capacity to repay a long-term mortgage loan, DHS can also serve to promote and reward a sustained saving effort. With this in mind, it is necessary to incorporate and maintain over time the requirement for prior saving as a requisite for being eligible for DHS.

\section{III}

\section{Latin American experience in the application of direct housing subsidies}

There are a number of Latin American countries which have direct housing subsidy programmes (Gonzáles Arrieta, ed., 1995). These instructive experiences (in Chile, Costa Rica, Colombia, El Salvador, Uruguay and Paraguay) listed in order of their length of past trajectory, will be summarized below and their main features, achievements and limitations will be noted in each case.

\section{Chile}

Chile is the pioneer in Latin America in the application of a system of housing subsidies of this type. In 1978 the Ministry of Housing and Urban Development (MINVU) began to use this system for the lower middle sector (dwellings costing up to US\$ 13,300 at the time: now equivalent to US\$27,200), in place of the subsidies implicit in the interest rates on mortgage loans or hidden in the sale price of building sites or dwellings. MINVU now operates a set of five housing programmes designed to serve the whole population that it is desired to aid. Each programme involves a direct subsidy paid to the purchaser of a dwelling in the form of a pre-announced non-repayable once-only contribution granted by the State to each beneficiary family that does not already own a dwelling. The DHS form part of a tripartite system of housing purchase finance: prior saving of the beneficiary family, the direct subsidy, and a long-term mortgage loan. The principles underlying these programmes are the subsidiary role of the State, the targeting of social expenditure, progressiveness, and the encouragement of saving.

MINVU grants DHS with resources from the public budget. The direct subsidies may be given in either a private or State-oriented form. The private modality consists of an endorsable certificate given to the beneficiary, who uses it to pay part of the cost of the selected dwelling, with the value of the certificate being later collected from MINVU by the vendor of the dwelling. In the State-oriented modality, which is used only for lower-cost dwellings, MINVU commissions the construction of the dwellings by tender and applies the subsidy directly to their cost, with the beneficiaries merely being informed of the details of the operation.

Table 1 summarizes the conditions of the housing programmes with a direct subsidy from MINVU. The eligibility requirements for the different programmes do not establish any differentiation according to applicants' income: it is the applicants themselves who enter a particular programme according to their aspirations, preferences and willingness to pay for a dwelling. The maximum values of the dwellings covered by the programme, the minimum saving requirements and the maximum subsidies are expressed in Development Units (“UF"): a unit of account whose value in pesos varies day by day according to the variation in the Consumer Price Index in the previous month.

The Progressive Housing Programme is designed for families living in a state of indigence and comprises two stages. The beneficiaries are selected according to the number of points they obtain: the lower their socioeconomic and housing status, the larger their family group and the longer they have been enrolled in the programme, the higher the number of points assigned to them. In this programme, which only began to operate in 1990, under the MINVU modality $100 \%$ of the subsidies approved are paid out, but under the private modality $10 \%$ of the persons granted subsidies do not make use of them within the time limit of 21 months. 
TABLE 1

Chile: Values of housing, subsidies, saving and loans under the housing programmes of the Ministry of Housing and Urban Development

(Values expressed in Development Units (UF))

\begin{tabular}{|c|c|c|c|c|c|}
\hline Programme & $\begin{array}{l}\text { Maximum value } \\
\text { of dwelling }\end{array}$ & $\begin{array}{l}\text { Maximum } \\
\text { subsidy }\end{array}$ & $\begin{array}{l}\text { Minimum } \\
\text { prior saving }\end{array}$ & Maximum loan & Other features \\
\hline $\begin{array}{l}\text { Progressive } \\
\text { Dwelling, Stage } 1\end{array}$ & 140 & 132 & 8 & - & $\begin{array}{l}\text { Collective or individual } \\
\text { projects, carried out } \\
\text { privately or by SERVIU }\end{array}$ \\
\hline $\begin{array}{l}\text { Progressive } \\
\text { Dwelling, Stage } 2\end{array}$ & 70 & 18 & 5 & 47 & $\begin{array}{l}\text { Collective or individual } \\
\text { projects, carried out } \\
\text { privately }\end{array}$ \\
\hline Basic Dwelling & $\begin{array}{l}230 \text { (SERVIU) } \\
400 \text { (private) }\end{array}$ & 140 & $\begin{array}{l}10 \text { (SERVIU) } \\
20 \text { (private) }\end{array}$ & $\begin{array}{c}80 \text { (SERVIU) } \\
100 \text { (private) }\end{array}$ & $\begin{array}{l}\text { Collective or individual } \\
\text { projects, carried out } \\
\text { privately or by SERVIU }\end{array}$ \\
\hline $\begin{array}{l}\text { Special Workers' } \\
\text { Programme }\end{array}$ & 400 & 90 & 40 & $\begin{array}{l}\text { Not more than } \\
65 \% \text { of price } \\
\text { of dwelling }\end{array}$ & Collective private projects \\
\hline $\begin{array}{l}\text { Rural Housing } \\
\text { Subsidy }\end{array}$ & $\begin{array}{l}260 \text { (individual } \\
\text { applications) } \\
400 \text { (collective } \\
\text { applications) }\end{array}$ & $\begin{array}{c}150 \text { (with } \\
\text { building plot) } \\
200 \text { (in housing } \\
\text { groups) }\end{array}$ & $\begin{array}{l}5 \text { (with building } \\
\text { plot) } \\
10 \text { (in housing } \\
\text { groups) }\end{array}$ & & $\begin{array}{l}\text { Collective or individual } \\
\text { private projects }\end{array}$ \\
\hline $\begin{array}{l}\text { Unified Subsidy, } \\
\text { Category I }\end{array}$ & 500 & $130-120-110$ & 50 & $\begin{array}{l}\text { Up to } 1,000 \mathrm{UF} \\
\text { but not more } \\
\text { than } 75 \% \text { of price } \\
\text { of dwelling }\end{array}$ & $\begin{array}{l}\text { Collective or individual } \\
\text { private projects }\end{array}$ \\
\hline $\begin{array}{l}\text { Unified Subsidy, } \\
\text { Category II }\end{array}$ & 1,000 & $110-100-90$ & 100 & $\begin{array}{l}\text { Up to } 1,000 \mathrm{UF} \\
\text { but not more than } \\
75 \% \text { of price } \\
\text { of dwelling }\end{array}$ & $\begin{array}{l}\text { Collective or individual } \\
\text { private projects }\end{array}$ \\
\hline $\begin{array}{l}\text { Unified Subsidy, } \\
\text { Category III }\end{array}$ & 1,500 & $90-80-70$ & 150 & $\begin{array}{l}\text { Up to } 1,000 \mathrm{UF} \\
\text { but not more than } \\
75 \% \text { of price } \\
\text { of dwelling }\end{array}$ & $\begin{array}{l}\text { Collective or individual } \\
\text { private projects }\end{array}$ \\
\hline Urban Renewal & $\begin{array}{c}\text { Up to } 500 \\
500-1,000 \\
1,000-1,500\end{array}$ & $\begin{array}{c}200-190-180 \\
\text { (all categories) }\end{array}$ & $\begin{array}{c}50 \\
100 \\
150\end{array}$ & Optional & $\begin{array}{l}\text { Collective or individual } \\
\text { private projects }\end{array}$ \\
\hline $\begin{array}{l}\text { Leasing of } \\
\text { dwellings }\end{array}$ & $\begin{array}{l}\text { Same categories } \\
\text { as the Unified } \\
\text { Subsidy }\end{array}$ & $\begin{array}{l}130 \text { (Category I) } \\
110 \text { (Category II) } \\
90 \text { (Category III) }\end{array}$ & $\begin{array}{l}\text { Methodical } \\
\text { deposits of rent } \\
\text { and of final } \\
\text { payment }\end{array}$ & - & Individual private projects \\
\hline
\end{tabular}

Source: Ministry of Housing and Urban Development (MINVU).

${ }^{\mathrm{a}}$ SERVIU $=$ Department of Housing and Urban Development. 
The Basic Dwellings Programme is aimed at families living in marginal housing conditions. In order to receive the benefits, applicants must have a certain level of prior saving and are selected according to the points system described above. This programme began to operate in 1984; the dwellings were constructed under the State-oriented modality (by tender) up to 1994 , when the private modality was introduced. By definition, $100 \%$ of the subsidies approved are actually paid out. About 25,000 dwellings per year are constructed under this programme (almost 20\% of the total number of dwellings built).

The Special Workers' Programme (PET), which was established in 1987, is aimed at organized groups of families and provides improved basic dwellings. The size of the subsidy given is smaller than in the following programmes applicable to higher-cost dwellings, since as there is no system of allocation on points it is possible to receive a dwelling much more quickly. The beneficiaries can apply to the banking system for a supplementary mortgage loan, but the private sector has not shown much interest in providing such loans, probably because of their relatively small amount, so MINVU guarantees access to a mortgage loan of up to $65 \%$ of the cost of the dwelling, supplied by the State-owned Banco del Estado. These loans are issued in the form of mortgage bills, which usually have a value below their nominal value when traded on the capital market. All or part of the difference is covered by MINVU, thus representing an additional subsidy with a current upper limit of about US\$ 2,600 per operation. ${ }^{2}$ Some 16,000 dwellings are financed each year through the PET, with $100 \%$ of the subsidies actually being paid out.

The Rural Subsidy System is aimed at low-income families living in localities with less than 2,500 inhabitants. It requires prior saving in the form of proof of ownership of a plot on which the dwelling can be built. In this programme, the socioeconomic and housing situation of the applicants is evaluated and the other criteria mentioned above are also applied. Around 8,000 dwellings are constructed each year under this programme, with over $90 \%$ of the subsidies approved actually being paid out.

\footnotetext{
${ }^{2}$ Initially, there was no upper limit on this implicit subsidy because it was desired to avoid situations where the beneficiary might be exposed to market fluctuations which could prevent him from making up the price of the dwelling, but in some cases the additional implicit subsidy can be as much as twice the size of the direct subsidy, thus militating against the progressiveness of the system (Melo, 1995, p. 37).
}

The Unified General Subsidy Programme is aimed at middle- and lower middle-income families who do not already own a dwelling but have a certain level of payment capacity that makes them eligible for bank loans. Under this system, the State subsidizes part of the cost of the dwelling through a certificate allocated under a non-personal application system. In order to make the subsidy progressive, the programme has three categories, depending on the value of the dwelling it is desired to acquire, with three forms of application: individual, collective, and for areas of urban renewal. Applicants under this programme are not ranked in socioeconomic terms but must provide proof that they do not already own another dwelling and that they have entered into a saving plan with some financial institution. The categories of values of eligible dwellings, the corresponding minimum prior savings required, and the levels of subsidy that can be applied for are shown in table 1 .

The beneficiaries have a time limit of 21 months for collecting their subsidies. The policy of MINVU has been to guarantee a loan through the Banco del Estado only for the first category of the programme. As in the case of the PET, MINVU grants these debtors an additional subsidy, with an upper limit of about US\$ 2,600 per operation, when the mortgage bills have to be sold at less than their face value. ${ }^{3}$ Once the dwelling is finished and it is transferred to the purchaser by official deed of ownership, the vendor of the dwelling can collect the value of the subsidy -for which purpose he must submit the mortgage bill to MINVU, endorsed in his favour- and the amount of the prior saving. Under this programme, MINVU has no direct involvement in the planning and execution of the housing projects. It is now permissible to use the subsidy to purchase a used dwelling, provided the operation is effected in the last nine months of validity of the subsidy. Historically, over $80 \%$ of the subsidies approved have actually been paid out. On average, over $70 \%$ of the subsidies approved correspond to category 1 , over $20 \%$ to category 2 , and less than $7 \%$ to category 3 .

\footnotetext{
${ }^{3}$ When there was no upper limit for this implicit subsidy, there were times when it was advantageous to apply for a loan even without any direct subsidy merely in order to obtain the implicit subsidy on the mortgage bills (Melo, 1995, p. 40). As from 1990 , the maximum amount of the implicit subsidy was limited to 80 UF per operation, and furthermore the loan eligible for the implicit subsidy could not exceed 1,000 UF, in order to avoid or reduce regressiveness of the system.
} 
The subsidies paid in respect of private-sector programmes, which include the Unified Subsidies, the PET and the Rural Subsidies, number approximately 50,000 per year, and between 1980 and 1996 a total of almost 850,000 subsidies had been paid. The subsidies in respect of the programmes for basic and progressive dwellings, for their part, number around 45,000 per year. Since some 120,000 dwellings per year are built in Chile at present, this means that the State plays a decisive part in the financing of approximately $80 \%$ of all the dwellings built, in proportions that range from $6 \%$ of the price for the middle-income sectors to $94 \%$ for the very poor sectors (Hermosilla, 1995, p. 21). In most cases (some $70 \%$ ) direct intervention by the State is limited to providing purchasing power through a direct subsidy for demand granted through transparent and objective processes of reception and selection of applications. Thus, since 1992 Chile has been producing more new dwellings than the demand generated annually by the formation of new households and obsolescence of the existing stock of dwellings.

In short, in Chile the system of access to housing which incorporates DHS covers all the income strata in a coherent manner, facilitating the access of the neediest sectors of the population to formal (albeit somewhat rigid) solutions to their housing needs, with the State playing a decisive role. The success achieved in the application of DHS is also due to the sustainability over time of the budgetary resources earmarked for the provision of subsidies: some US\$ 400 million are currently set aside for this purpose, of which over $92 \%$ corresponds to the actual subsidies and less than $8 \%$ to administrative expenses.

In the course of the operation of the system it has been necessary to make some improvements in order to secure greater efficiency and equity. ${ }^{4}$ One of the main aspects that had to be improved was the targeting of the subsidies (Castañeda, 1990), since the programmes originally aimed at the lowest-income

\footnotetext{
${ }^{4}$ An increase in efficiency has been noted, because in spite of smaller fiscal expenditure it has been possible to mobilize more resources to housing, much of the construction being carried out by the private sector. There has also been a notable improvement in equity: the proportion of subsidies going to the poorest $30 \%$ of the population has more than doubled, rising from $21 \%$ in 1969 and 1980 to 50\% in 1985-1986 (Castañeda, 1990, p. 176).
}

strata mainly benefitted the middle-income sectors, because the prior saving requirements were excessively high, the investigation of the economic situation of applicants was not effective, and the dwellings offered were relatively expensive. In view of this, special programmes were introduced to serve the middle and upper-middle income groups, while the programmes designed for the poorest sectors have sought to achieve a better balance between the minimum prior saving required, the payment capacity of the applicant, and the cost of the dwelling offered.

The original Unified General Subsidy Programme was also modified in various respects, such as the housing cost categories, the quotas per region, the amount of the subsidies, their period of validity, the possibility of collective applications, etc. Recently the Programme has been broadened to include direct subsidies deferred in time, to be used with the new system of renting dwellings with an undertaking for their subsequent purchase (leasing), aimed at those who wish to acquire a dwelling costing up to around US\$ 48,000. Under this modality, the State can either grant a subsidy ${ }^{5}$ that MINVU pays out in successive equal quarterly installments for up to 20 years, thus reducing the burden on the beneficiary's budget in respect of the rent, or it can pay it out immediately so that the beneficiary can buy a better and more expensive dwelling.

The Chilean experience is also valuable because it confirms in practice some of the advantages theoretically attributed to DHS: the granting of explicit direct subsidies not only means greater transparency but is also compatible with the principle of the subsidiary role of the State and the functioning of a market economy; the establishment of objective criteria for the selection of applicants, subject to ongoing review in the light of targeting criteria, guarantees the credibility of the system; the stratification of the subsidies by housing value categories makes it possible to ensure the progressiveness of the system; the requirement for methodical saving as a requisite for obtaining the subsidy enhances the likelihood that beneficiaries will subsequently be capable of servicing a mortgage loan, as well as representing an important stimulus for family saving; and the

\footnotetext{
${ }^{5}$ This system of leasing can also operate without a direct housing subsidy.
} 
possibility of collective applications has the advantage that a group form of organization tends to maintain itself in time and facilitate the fulfillment of its individual members' application commitments.

The work done in this field in Chile also shows the need to overcome two major difficulties: on the one hand, the limited willingness of the private sector to enter into the financing of low-cost dwellings, which means that the public sector must play a preponderant role in this respect, and on the other, the absence of a secondary market for low-cost dwellings of the type covered by the subsidies. It is aimed to promote such a market by permitting greater neutrality in the use of direct housing subsidies for either new or used dwellings.

\section{Costa Rica}

In Costa Rica, the system of direct housing subsidies, called "Family Housing Certificates", has been in operation since 1987 when the National Housing Finance System was set up. The State-owned Housing Mortgage Bank administers these subsidies, which are channelled with the backing of the Housing Subsidy Fund. The Certificates are granted by the State, on a once-only basis, to families with a monthly income equivalent to less than four minimum monthly wages of a skilled construction worker (a total of some US\$ 700). To begin with, the Certificates consisted of a supplementary interest-free loan, but later on they were changed into a non-repayable grant. The Certificates are not actually delivered in the form of a certificate but in the form of documents attesting to the technical characteristics of the dwelling and the situation of the nuclear family receiving the benefits. The origin of the Housing Subsidy Fund resources applicable to the Certificates is laid down by law and includes the levying of certain taxes and a percentage of the national budget.

The maximum value of the Certificates cannot exceed the equivalent of 30 times the minimum wage mentioned earlier (i.e., some US\$ 5,200). This maximum subsidy is given to families receiving an income of up to one minimum wage and is currently set at the equivalent of some US\$4,800. In the case of families receiving between one and four minimum wages, the subsidy is granted on a partial basis in inverse proportion to the family income (table 2). As the subsidies are calculated in steps of 20 , there are approximately 80 different amounts of subsidy, in line with the small differences in family income. ${ }^{6}$ Since this maximum subsidy does not cover the maximum value of a normal low-cost dwelling (estimated at around US\$ 14,072), the subsidy is accompanied by a 15 -year mortgage loan granted by authorized institutions. Since 1 April 1995, the interest rate (which was previously fixed by the Housing Subsidy Bank) is fixed freely by the institutions authorized by the National Housing Finance System.

These authorized institutions classify the families applying for subsidies and determine the maximum cost of the dwelling they wish to obtain, the amount of credit to be extended, and the down payment required. The subsidy and the credit always go together in a single package administered by the authorized institution. The system only provides for individual applications. The Housing Mortgage Bank is responsible for approving and paying out to the authorized institution the amount of the subsidy for the successful applicants, subject to verification of the amounts determined by each institution.

The Family Housing Certificate programme includes various sub-programmes, and the subsidies can be used to buy a new or used dwelling, to buy a plot of land and build on it, to make improvements or repairs to dwellings, to build a dwelling on a plot belonging to the applicant and, more recently, to buy a building site.

With the present values of the Certificates, in the lowest-income category (i.e., up to one minimum wage) the direct subsidy may cover at least two-thirds of the cost of a basic housing solution, but as the maximum cost of a normal low-cost dwelling is estimated at US\$ 14,072 , in the case of that category of applicants the subsidy only represents a very low proportion (34\%) of such a dwelling. The values of the certificates can be readjusted by the Housing Mortgage Bank up to a ceiling of 30 times the minimum wage, but in Costa Rica there are no arrangements for the automatic readjustment of the amounts of the subsidies or of the cost of a dwelling for each category. The authorities periodically raise the nominal amounts of the subsidies, but their real value usually lags behind inflation.

\footnotetext{
${ }^{6}$ In each case the calculation depends on the family income and is carried out according to the following formula: value of Family Housing Certificate $=1,394,000-[336,000 \times$ social stratum], where the social stratum is the ratio between the gross income of the family and the current minimum wage.
} 
TABLE 2

Costa Rica: Calculation of Family Housing Certificate and supplementary credit, by income brackets ${ }^{\mathrm{a}}$

(In current dollars at 31 December 1996)

\begin{tabular}{|c|c|c|c|c|c|c|}
\hline $\begin{array}{c}\text { Wage } \\
\text { stratum }\end{array}$ & $\begin{array}{l}\text { Gross } \\
\text { income }\end{array}$ & $\begin{array}{l}\text { Monthly } \\
\text { installment }\end{array}$ & $\begin{array}{l}\text { Capacity for } \\
\text { indebtedness }\end{array}$ & $\begin{array}{c}\text { Minimum } \\
\text { contribution } \\
\text { by beneficiary }\end{array}$ & $\begin{array}{c}\text { Maximum } \\
\text { Family Housing } \\
\text { Certificate }\end{array}$ & $\begin{array}{c}\text { Maximum } \\
\text { value of housing } \\
\text { solution }\end{array}$ \\
\hline - & - & - & - & - & 4802.5 & 4802.5 \\
\hline 0.50 & 86.5 & 26.0 & 1132.4 & - & 4802.5 & 5935.0 \\
\hline 1.00 & 173.0 & 51.9 & 2264.9 & - & 4802.5 & 7067.4 \\
\hline 1.50 & 259.5 & 77.9 & 3397.3 & 169.9 & 4039.9 & 7607.1 \\
\hline 2.00 & 346.0 & 103.8 & 4529.8 & 226.5 & 3277.3 & 8033.6 \\
\hline 2.50 & 432.5 & 129.8 & 5662.2 & 283.1 & 2514.8 & 8460.1 \\
\hline 3.00 & 519.1 & 155.7 & 6794.6 & 339.7 & 1752.2 & 8886.5 \\
\hline 3.50 & 605.6 & 181.7 & 7927.1 & 396.4 & 989.6 & 9313.0 \\
\hline 4.00 & 692.1 & 207.6 & 9059.5 & 453.0 & 227.0 & 9739.4 \\
\hline
\end{tabular}

Source: Housing Mortgage Bank (BANHVI).

${ }^{a}$ The calculations are based on the following parameters:

Repayment term: 180 months.

Annual interest rate: $27 \%$.

Ratio of installment to income: $30 \%$.

Minimum wage: 38,116 colones

Maximum subsidy: $1,058,000$ colones (equals 27.8 minimum wages).

Minimum subsidy: 50,000 colones (equals 1.3 minimum wages). Exchange rate (interbank rate at 31 Dec. 1996): 220.30 colones per dollar

Unlike the Chilean system, the Costa Rican DHS scheme does not make any requirement for the methodical accumulation of prior saving in one of the institutions authorized by the National Housing Finance System. The beneficiary's contribution may be made in the form of voluntary saving of a minimum amount required for the basic loan, or through unskilled labour in a supervised self-build process. Families whose income is not more than one minimum wage are not obliged to make a down payment or a minimum contribution. To back up the mortgage loans granted, the National Housing Finance System has made arrangements for the rediscounting of Housing Mortgage Bank mortgages through the National Housing Fund. It is estimated that so far $45 \%$ of all the credit operations carried out by the $\mathrm{Na}$ tional Housing Finance System have involved Family Housing Certificates.

From the establishment of the National Housing Finance System up to September 1996, 118,727 housing subsidies worth a total of US\$ 332 million were granted, thus benefitting an equal number of families with an income of up to four minimum wages (approximately $18 \%$ of the population). Between 1990 and 1993, an average of 15,636 subsidies were granted each year. Nearly $59 \%$ of all the subsidies granted went to families living in rural areas (Monge, 1995, p. 64). Out of the total number of subsidies granted between the beginning of operations and June 1995, 42\% of the applications approved were for the construction of a dwelling on a plot already owned by the applicant, $31.5 \%$ were for the acquisition of a building site and the construction of a dwelling on it, $26 \%$ were for the purchase of an existing dwelling, and $2 \%$ were for repairs or improvements. ${ }^{7}$

According to official sources, the total amount of resources allocated to the subsidy programme has represented an average of approximately $3 \%$ of public social expenditure since 1987. Over that period, however, the Housing Mortgage Bank has not received the whole of the resources laid down by law (3\% of the national budget): it is calculated that only about $40 \%$ of that amount has actually been transferred to it.

Approximately $65 \%$ of the new dwellings built and sold each year include a subsidy component. Taking account of the subsidies granted and the transactions completed outside the system, it is estimated that in recent years it has been possible to pre-

\footnotetext{
${ }^{7}$ The dollar figures for each year were calculated at the average interbank exchange rate for each year.
} 
vent an increase in the housing deficit. Since 1992, for the first time, the number of dwellings financed has covered the minimum annual needs and has made it possible to begin to reduce the accumulated deficit (Zawadzki, 1993, p. 24). Furthermore, the Costa Rican DHS programme has proportionately favoured the lowest-income groups: almost $79 \%$ of all the subsidies granted have gone to families with an income of not more than two minimum wages (US\$ 350). This targetting through direct subsidies has been strengthened with time, since the proportion of certificates actually paid out to the lowest-income sectors rose from $65 \%$ in 1987 to $97 \%$ in 1996. Since the mortgage loans are linked with the subsidy, this also means that the mortgage credit provided by the authorized institutions has also reached these sectors. This is one of the most notable positive features of the Costa Rican system, since in other countries low-income beneficiaries of DHS have had great difficulty in gaining access to mortgage loans.

The Family Housing Certificates are an instrument which really has made it possible to increase low-income families' possibilities of gaining access to housing. A family with an income equivalent to three minimum wages which receives a DHS is thus provided with a purchasing power that enables it to obtain a dwelling that -without the subsidy- would only be within the reach of a family with an income of around four minimum wages. The certificates also have a progressive income redistribution impact: the lower the income level of a family, the higher the amount of the subsidy it receives and the greater the percentage increase in its purchasing power by this means (Monge, 1995, pp. 64-65).

In addition to the direct subsidy, however, up to 1995 there was also an indirect subsidy through the interest rates charged on the mortgage loans granted by the authorized institutions. The decision taken in April 1995 to free interest rates for the housing sector was designed to eliminate this indirect subsidy, thus concentrating the government's efforts on direct assistance for the neediest and doing away with this distortion in the functioning of the financial market (Arroyo, 1995, p. 49). The establishment of a requirement for methodical prior saving in order to obtain a subsidy is also under consideration, since the current absence of such a requirement is considered to be one of the main shortcomings in the Costa Rican DHS system. A requirement for prior saving would also facilitate the objective allocation of subsidies on a points system.

\section{Colombia}

In Colombia, the Family Housing Subsidy was established in 1991. The bodies responsible for administering and granting the subsidies are, in urban areas, the National Low-Cost Housing and Urban Reform Institute (INURBE) and the Family Welfare Agencies and, in rural areas, the Agricultural, Industrial and Mining Credit Agency. The design of the DHS system in Colombia is particularly complex (there are various institutions involved in the granting of such subsidies and multiple scales of maximum values of dwellings and subsidies), and furthermore it has undergone numerous changes since its introduction.

The Family Housing Subsidy is a once-only non-repayable contribution by the State in money or kind (land, building materials, ownership deeds, etc.). It is intended for households with an income of not more than four legal minimum wages, currently equivalent to a total of about US\$ 568 . The beneficiaries can choose for themselves the housing solution for which they aim to use the subsidy. When in the form of money, the subsidy is given to the body or person who provided or financed the housing solution of the beneficiary, against presentation of the certificate of sale or improvement. Subsidies are also provided in kind, either in the form of building plots belonging to INURBE or the title deeds to a considerable number of lots which were invaded before 1989. The traditional source of finance for the DHS programme is the regular central government revenue.

Beneficiaries must make a prior contribution in money or kind. Applications can be collective as well as individual. Beneficiaries are selected on the basis of a household qualification process and a points system, taking into account such criteria as family income, the value of the housing solution, the size of the prior contribution, the number of dependants in the family, etc. The subsidies must be used within 18 months of their award.

The DHS system has two branches: the first, which forms part of the Social Solidarity Network, is aimed at households with a monthly income of not more than two legal minimum wages (about US\$ 284), while the second is intended to provide new dwellings for households with an income between two and four minimum wages (about US\$ 568). The first-named branch is further divided into two programmes: a programme for the improve- 
TABLE 3

Colombia: Maximum amounts of Family Housing Subsidy, by mode of use and population of area where dwelling is located

(Figures in dollars and Constant Purchasing Power Units (UPACs)

\begin{tabular}{ll}
\hline & $\begin{array}{c}\text { Population of area where dwelling is located } \\
\text { (number of inhabitants) }\end{array}$ \\
\cline { 2 - 3 } Type of housing solution/institution granting subsidy & $<100,000 \quad 100,000-500,000$ \\
\hline
\end{tabular}

A. For households with an income of not more than two legal minimum wages

Integral improvement of dwelling and environment (INURBE only)

Construction of dwelling on own site and improvement of dwelling (INURBE and Family Welfare Agencies) or integral improvement of dwelling and environment (Family Welfare Agencies)

$\begin{array}{ccc}\text { US\$ } 2,058 & \text { US\$ } 2,058 & \text { US\$ } 2,058 \\ (210 \text { UPAC }) & (210 \text { UPAC }) & (210 \text { UPAC) } \\ & & \\ \text { US\$ } 2,450 & \text { US\$ } 2,450 & \text { US\$ } 2,450 \\ (250 \text { UPAC }) & (250 \text { UPAC }) & (250 \text { UPAC })\end{array}$

Acquisition or acquisition and construction of basic unit, basic unit for progressive development or minimum dwelling (INURBE)

$\begin{array}{ccc}\text { US\$ 2,450 } & \text { US\$ 2,940 } & \text { US\$ 3,430 } \\ (250 \text { UPAC }) & (300 \text { UPAC }) & (350 \text { UPAC }) \\ & & \\ \text { US\$ 3,430 } & \text { US\$ 3,920 } & \text { US\$ 4,410 } \\ (350 \text { UPAC }) & (400 \text { UPAC }) & (450 \text { UPAC) }\end{array}$

Acquisition or acquisition and construction of basic unit, basic unit for progressive development or minimum (350 UPAC)

B. For households with an income between two and four legal minimum wages

\begin{abstract}
Improvement of dwelling or construction on own site
\end{abstract}
Acquisition or acquisition and construction of basic unit, basic unit for progressive development or minimum dwelling

\begin{abstract}
US\$2,058
\end{abstract}
(210 UPAC)

US\$2,058

(210 UPAC)
US\$2,058

(210 UPAC)

US\$ 2,450

(250 UPAC)
US\$2,058

(210 UPAC)

US\$ 2,940

(300 UPAC)

Source: National Low-Cost Housing and Urban Reform Institute (INURBE).

ment of dwellings and their environment, including the legal accreditation of the title deeds of dwellings, and a programme for the provision of new dwellings.

The maximum values of the low-cost dwellings for which the DHS can be used are expressed in monthly legal minimum wages, are readjusted once a year, and are determined as a function of the population size of the cities where they are located and the monthly income of the beneficiary family: for families with an income of up to two minimum wages, the maximum value of the dwelling is equivalent to about US\$12,800, while for families with an income of between two and four minimum wages the maximum value is equal to US\$19,200. Table 3 shows the maximum amounts of the subsidies, which are expressed in Constant Purchasing Power Units (UPAC) ${ }^{8}$ and depend on the socioeconomic situation of the beneficiaries, the type and value of the housing solution selected, and the population of the city where it is located.
In order to receive a DHS, beneficiaries must make a certain minimum contribution. The mortgage loans available are complementary to the subsidy and are generally used by households with an income between two and four legal minimum wages. Generally speaking, for this segment of families the subsidy, plus the families' contribution in money, cover $30 \%$ of the value of the dwelling and the remainder is financed with a 15-year mortgage loan.

From the inception of the DHS programme up to September 1996, INURBE, which accounts for almost half the subsidies granted in the country, approved a

\footnotetext{
${ }^{8}$ This is a unit established under Decree No. 1229 of 17 July 1972 as a mechanism for the monetary correction of savings and loans in Savings and Loan Corporations. At first, it was laid down that the peso equivalences of UPACs should be corrected daily in line with the index of inflation, but after successive changes in the manner of calculation of the readjustment the value of the UPAC depends basically on the changes in the market interest rate on deposits.
} 
total of 270,932 subsidies, of which only $49 \%$ have actually been paid out. For the provision of those subsidies, US\$ 486 million was earmarked and US\$ 226 million was actually disbursed (46.5\%). The proportion of effective disbursements of the subsidy is thus very low compared with the number and value of the subsidies approved.

The main uses of the DHS have been for the purchase of building lots with services (32\%) and the improvement of existing dwellings (26\%). The financing of building lots has no longer been permitted since 1994, as it was found that the granting of a subsidy did not always guarantee that a dwelling would be built. According to a study by the National Centre for Construction Industry Studies (CENAC), 90\% of the dwellings technically classed as low-cost attracted this benefit, which is a clear indicator of the broad coverage of the programme. Some $80 \%$ of the total number of direct housing subsidies approved have gone to the population segment with a family income of not more than two legal minimum wages.

One of the main weaknesses in the Colombian DHS programme, however, is the very small proportion of the total cost of the dwelling covered by the subsidy: if we take the maximum subsidy established and the maximum permissible cost of the dwelling, the subsidy only covers $27 \%$ of the cost of the housing solution in the case of the lowest income strata. This situation, together with these groups' limited capacity to save and to gain access to mortgage loans, helps to explain the relatively high proportion (rather more than a quarter) of subsidies approved but never used. Furthermore, too much time elapses between the approval of the subsidy and its actual disbursement: the average length of time that an applicant has to wait to actually receive the subsidy after its approval is 14 months. An evaluation of the programme made by the authorities in 1994 (Salazar, 1995) found a number of other problems, including the fact that purchasers of dwellings with an income of 135 legal minimum wages have received subsidies without of course needing them, and that the stratum with an income between one and four minimum wages does not have effective access to credit. In spite of this, the changes which have been made have left some very typical problems of the programme untouched, such as the low proportion of the price of housing solutions covered by the subsidy, even for the sectors with the lowest incomes.

\section{El Salvador}

In El Salvador, a DHS system was established in 1992 called the Contributions for Housing Programme, administered and awarded by the National People's Housing Fund (FONAVIPO), which was set up in the same year. The Contributions for Housing are State contributions in cash or kind granted to the beneficiary families on a once-only and non-repayable basis. In this case, the contribution is intended basically for the improvement of dwellings and not for the purchase of completed housing, which makes it markedly different from the schemes operating in Chile and Costa Rica. The contributions are granted in the form of a certificate issued by FONAVIPO in favour of the beneficiary and negotiable only through the institutions authorized to participate in the Programme.

By law, the resources for the Programme are to come from a special fund administered by FONAVIPO and made up of the net assets of the former Urban Housing Institute (IVU), which are to be administered to turn them into cash. The law also authorizes FONAVIPO to receive budgetary items from the central government, although so far the Programme has not obtained any funds in this way.

Beneficiaries must have a monthly family income of not more than two minimum wages (currently US\$ 264), their current dwelling must be below the minimum acceptable housing conditions, and they must own the building or site. Selection is carried out on a points system whose basic components are the effort made by the applicant, the value of the housing solution, the length of time the applicant has been in the system, and the family's poverty status.

The Programme currently operates under three modalities: Individual Dwelling Improvement, New Organized Settlements, and Credit for a New Dwelling, with Contribution. ${ }^{9}$ The Individual Dwelling Improvement modality is aimed at families which own a dwelling in poor conditions of habitability, or families which own a plot of land and are living in a makeshift dwelling. The New Organized Settlements modality is aimed at families currently living in dan-

\footnotetext{
${ }^{9}$ Two more modalities are under consideration: Neighbourhood Improvement, and Credit for Individual Dwelling Improvement, with Contribution. The latter modality is aimed at families with some capacity to repay a loan.
} 
gerous areas, areas subject to expropriation, areas set aside for tourism or nature reserves, or areas illegally occupied by them, and who are willing to be moved voluntarily to a plot of land which will belong to them. The Credit for a New Dwelling, with Contribution, is likewise aimed at families with an income of not more than two minimum wages, but with the difference that they do not own a dwelling or site of their own. The above modalities allow the subsidies to be used for the improvement or construction of a dwelling, part payment for the purchase of a building site (only $25 \%$ of the maximum subsidy can be used in this manner), and the improvement of housing and communal services. The Programme allows for either individual or collective applications and leaves it to the families to decide what aspect of their housing deficit they wish to cover.

The amount of the contribution is between four and twelve minimum wages, depending on how precarious the applicants' housing conditions are. If we compare the maximum value of the subsidy (about US\$ 1,584) with the estimated value of a dwelling under the New Organized Settlements modality (between US\$ 1,730 and US\$ 1,950), we see that the DHS covers $81 \%$ or more of the cost of the dwelling. The values of the subsidies can only be changed in line with changes in the urban minimum wage, which is determined by the Ministry of the Economy. The prior saving that families with an income of up to one minimum wage and between one and two minimum wages must fulfill is $8.33 \%$ and $15 \%$ of their income, respectively. Under the New Organized Settlements modality, the required family effort consists of their willingness to be voluntarily transferred from the dangerous or illegally occupied site where they currently live to the new settlement where they will own their dwelling. Under the Credit for a New Dwelling, with Contribution modality, the mortgage loan to make up the price of the dwelling is provided by authorized institutions. Under this modality, it is possible to acquire dwellings with a cost of up to US\$ 3,429; the corresponding credit can be up to US\$ $1,845(53.8 \%)$ and the subsidy up to US\$ 1,584 (46.2\%).

From the date when it began operations up to December 1996, the Contributions for Housing Programme has approved nearly 27,000 housing subsidies worth almost US\$ 30 million. No funds have been provided from the national budget for this purpose, although the Law setting up FONAVIPO provides for this. Since 1993, when $46 \%$ of the whole Programme was achieved in terms of the number of subsidies approved and $33 \%$ in terms of the value of subsidies granted, there has been a marked slackening in the Programmes's activities, mainly because of the limited availability of resources. In its first five years of operation, $60 \%$ of the resources disbursed was for the improvement of existing dwellings, while the remaining $40 \%$ was for the New Organized Settlements modality, under which new dwellings are built. It is estimated that $75 \%$ of the subsidies granted went to families with an income of less than half a legal minimum wage (currently US\$ 66), while the remaining $25 \%$ went to families with an income of around one minimum wage (currently US\$ 132).

According to official sources, the Programme's contribution to the reduction of the housing deficit of the lowest-income sector of the population has been of the order of $6 \%$. This should be interpreted in the light of the fact that this scheme does not aim to provide a finished dwelling: its impact must be measured rather in terms of the gradual improvement of the qualitative deficit affecting existing dwellings (Bertrand, 1995).

\section{Uruguay}

In Uruguay, DHS are provided under the Integrated System of Access to Housing (SIAV), which began in 1993. The Ministry of Housing, Territorial Planning and the Environment, set up in 1991, administers and grants DHS. The SIAV was set up under the new housing policy initiated in 1991, backed up by a loan from the Inter-American Development Bank (IDB). The DHS granted by the State to families with an income equivalent to not more than 60 Readjustable Units ${ }^{10}$ can take two forms: the provision of an Expandable Basic Nucleus (NBE), built by private sector firms by tender, or the issue of a Direct Housing Subsidy Certificate (CSHD).

\footnotetext{
10 The Readjustable Unit (UR) is a unit of account created in 1968 under the National Housing Act (Law No. 13.728), and its value is currently corrected monthly as a function of the variation of the average wage index. As at 31 December 1996, one UR was equivalent to 141.14 pesos (about US\$ 16).
} 
TABLE 4

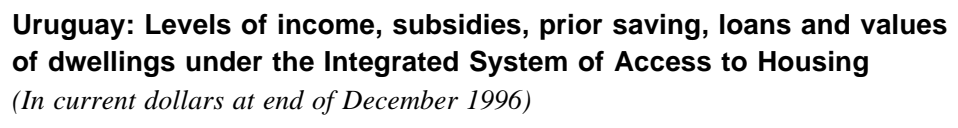

\begin{tabular}{cccccc}
\hline Income level & Subsidy level & $\begin{array}{c}\text { Minimum } \\
\text { prior saving }\end{array}$ & $\begin{array}{c}\text { Maximum } \\
\text { subsidy }\end{array}$ & Maximum loan & $\begin{array}{c}\text { Maximum value } \\
\text { of dwelling }\end{array}$ \\
\hline $0-480$ & NBE $^{\text {a }}$ & 80 & 18320 & - & 18400 \\
$480-705$ & I & 1040 & 12000 & 9360 & 22400 \\
$705-865$ & II & 2640 & 9120 & 13840 & 25600 \\
$865-960$ & III & 5950 & 5980 & 16870 & 28800 \\
\hline
\end{tabular}

Source: Ministry of Housing, Territorial Planning and the Environment.

${ }^{\mathrm{a}} \mathrm{NBE}=$ Expandable Basic Nucleus.

The DHS system is financed from the National Housing and Urban Development Fund (FNVU), administered by the Ministry of Housing, whose main source of resources (almost $85 \%$ of the total) is a $1 \%$ payroll tax.

In order to be eligible to apply for and receive a subsidy under the SIAV, a family must fulfill two conditions: it must be enrolled in the National Register of Subsidy Applicants, which maintains updated information on the situation of the households concerned, and it must have built up a certain level of prior saving in the bank before the time limit set for the period of application in question. At present, only individual applications are permitted. The beneficiaries are selected on a points system based on two criteria: first, the saving effort made and the length of time the family has been saving, for which purpose the number of Readjustable Units saved is multiplied by a weighting factor which is an inverse function of the socioeconomic level of the family, in order to increase the probability that the poorest families will be benefitted, and second, the size of the family unit.

The type of housing solution available and the size of the subsidy that a family can obtain depend on the latter's monthly income. Families with the lowest income levels are offered a housing solution which is almost completely covered by the subsidy. As families' income levels rise, the higher is the price of the housing solution open to them, the larger the amount of prior saving required, and the smaller the subsidy they will receive. All these values are expressed in URs. The size of the complementary mortgage loan available is also directly related to the family income level (table 4).

This stratification of demand means that for families with an income of not more than 30 UR (some US\$ 480) the State can provide a subsidy which covers almost the whole cost of the housing solution open to the families in question (some US\$ 18,400); the remainder is covered by the required minimum prior saving. The certificate issued to beneficiaries lasts for 18 months (non-renewable), and can be used for the purchase of an Expandable Basic Nucleus dwelling built by the private sector under contract to the Ministry of Housing, the purchase of a new or used dwelling on the open housing market, the construction of a dwelling on the applicant's own site, or the acquisition of a building site and the construction of a dwelling on it.

In the case of families with an income between 30 and 60 UR (between US\$ 480 and US\$ 960) there are three different levels of subsidy, with the maximum subsidy representing a decreasing proportion of the maximum price of the available dwellings as the family's income bracket rises. In these cases, the desired housing solution is achieved by presenting, in addition to the Direct Housing Subsidy Certificate, a certain amount of prior saving and a mortgage loan granted by one of the private or public financial intermediaries authorized to operate under the Integrated System of Access to Housing, on terms freely accorded between the applicant and the lender. The dwellings corresponding to each income level, with maximum prices laid down by law, are built by private construction firms. The financial intermediaries can rediscount both mortgage loans complementary to the DHS and loans for financing the construction of housing projects approved by the Ministry of Housing, through the Rediscount Fund, which is also financed with resources from the National Housing and Urban Development Fund and is run as a second-tier bank by the Central Bank of Uruguay. 
The Integrated System of Access to Housing identifies families with an income over 60 RU (over US\$ 960) as suitable subjects for credit because of their saving and repayment capacity, so families in this sector have to make use of the market real estate and financial schemes, including among the latter the Mortgage Bank of Uruguay. The access of this sector to housing depends exclusively on prior saving and a mortgage loan on market terms.

In the first year of operation of the DHS system (1993-1994), during which three invitations for applications were made, the Ministry of Housing issued a total of 7,367 certificates, of which $68 \%$ corresponded to certificates for the acquisition of Expandable Basic Nucleus dwellings and the remaining $32 \%$ to certificates for beneficiaries in levels I to III. Bearing in mind that Uruguay is a small country, this is quite a large number of subsidies for such a short time, and it is estimated that it has made it possible to cover nearly $10 \%$ of the housing deficit which existed.

The degree of targetting in this initial period was quite satisfactory and ensured that the neediest section of the population had the greatest probability of receiving a benefit (Romay, 1995, pp. 128-129). The families in a relatively easier position had to make four times as great a saving effort as the poorest households in order to receive benefits. Thus, the households with the greatest housing needs saved for an average of nine months, while those in a better socioeconomic situation had to save for over 50 months in order to receive benefits.

Under this scheme, the Expandable Basic Nucleus dwellings make possible a quicker housing solution for a larger number of families, especially the poorest ones, and they represent an important advance in terms of the quality of life of the beneficiary families, compared with the housing solutions thrown up in makeshift settlements. Furthermore, the DHS has helped to stimulate saving through the formal financial system (Romay, 1995, p. 149). Among the weaknesses of the scheme are the fact that in practice the only financial institution that participates actively in the Integrated System of Access to Housing is the Mortgage Bank of Uruguay and that the DHS system has not been capable of stimulating a significant private supply of new low-cost dwellings, so that many beneficiaries have used the subsidy to buy used dwellings.

\section{Paraguay}

In Paraguay the Direct Housing Subsidy System has been formally in operation since 1992, but its real implementation began in 1995. This system was established as part of the reordering of the housing sector carried out with the aid of two loans from the Inter-American Development Bank (IDB). The National Housing Council (CONAVI), set up in 1990, is responsible for administering the DHS system.

The DHS are a once-only non-repayable form of direct State aid granted to beneficiary families in order to enable them to purchase, build or improve a low-cost dwelling. The subsidies are issued in the form of a certificate which lasts for 18 months from its date of issue and is transferred by beneficiaries to the builder of the dwelling in part payment for the latter. CONAVI pays out the certificates to vendors of dwellings or to beneficiaries who are building on their own sites.

In order to implement the system, two funds were set up, both administered by CONAVI: the Direct Housing Subsidy Fund, and the Mortgage Rediscount Fund, through which CONAVI rediscounts the mortgage loans granted to beneficiaries by the financial intermediaries. These intermediaries are any banking or financial institution regulated by the Central Bank of Paraguay or by the National Housing Bank, as appropriate, or any legally constituted cooperative authorized by CONAVI. By law, the resources of the Direct Housing Subsidy Fund can come from general budget items, domestic and foreign loans, etc.

Beneficiaries must make a prior contribution, which can consist of savings, a building site of their own, labour, or any other form of contribution laid down by CONAVI. In the case of savings, the applicant must have an account in one of the intermediaries that participate in the programme. Applicants must have a family income which does not exceed the maximum for each level of subsidy, as laid down in the established stratification, and they must not already own a dwelling. Only individual applications are allowed. The selection of beneficiaries takes account of the level of subsidy requested and the geographical area where the desired dwelling is located; the final selection is based on a points system which takes into account such criteria as the amount of prior saving, the length of time the applicant has been saving, and the size of the family group. 
TABLE 5

Paraguay: Levels of income, subsidies, prior saving, loans and maximum value of dwellings under the direct housing subsidy system

(In dollars at the December 1996 exchange rate)

\begin{tabular}{cccccccc}
\hline Level of subsidy & $\begin{array}{c}\text { Monthly } \\
\text { family } \\
\text { income }\end{array}$ & $\begin{array}{c}\text { Direct } \\
\text { subsidy }\end{array}$ & $\begin{array}{c}\text { Minimum } \\
\text { prior saving }\end{array}$ & $\begin{array}{c}\text { Maximum } \\
\text { loan }\end{array}$ & $\begin{array}{c}\text { Maximum } \\
\text { value of } \\
\text { dwelling }\end{array}$ & $\begin{array}{c}\text { Valuation for } \\
\text { construction }\end{array}$ & $\begin{array}{c}\text { Valuation for } \\
\text { expansion or } \\
\text { rehabilitation }\end{array}$ \\
\hline I & $779-1053$ & 2748 & 1832 & 15114 & 19694 & 7878 & 13786 \\
II & $573-779$ & 3435 & 1145 & 10763 & 15343 & 6137 & 10740 \\
III & $366-573$ & 4122 & 687 & 7099 & 11908 & 4763 & 8336 \\
IV & $229-366$ & 4809 & 229 & 4351 & 9389 & 3756 & 6572 \\
V & Up to 229 & 5496 & 115 & 1832 & 7328 & 2931 & 5130 \\
\hline
\end{tabular}

Source: National Housing Council (CONAVI).

The subsidies granted can be used in either of two subprogrammes: the Housing Solution Acquisition Programme, which covers the purchase of new or used dwellings, and the Own Site Housing Solution Programme, which covers the construction, expansion or repair of dwellings. The Paraguayan DHS system has five levels of subsidies, depending on applicants' income, with each level being divided into the above-mentioned subprogrammes. Each of the five levels is subject to maximum levels of dwelling price and subsidy, minimum levels of prior saving, and maximum levels of mortgage credit, when this is required (table 5). These values are fixed in Minimum Wage Units. ${ }^{11}$

As may be noted from the foregoing, the system is progressive, not only in that the smaller the family income, the larger the subsidy and the smaller the prior saving required in absolute terms, but also in that the subsidy represents a larger proportion of the maximum cost of the dwelling. The DHS cannot exceed $75 \%$ of the cost of the dwelling. The system provides for the possibility of a mortgage loan to beneficiaries, at a variable interest rate, to make up the total cost of the dwelling. The repayment installments are adjusted automatically in line with the Minimum Wage Unit, and possible discrepancies between these two indexes will be reflected in the repayment periods.

From the inception of the system in September 1995 to November 1996 there were five invitations for applications and a total of 7,541 subsidies were approved, of which the equivalent of $16 \%$ was actually paid out. A total of US\$ 32.7 million was earmarked for the payment of this number of subsidies, but only US\$ 5.8 million was actually paid out (only $18 \%$ of the earmarked amount). Of the subsidies approved, $85 \%$ corresponded to the Housing Solution Acquisition subprogramme, while the remaining $15 \%$ went to the Own Site Housing Solution subprogramme. It should be noted that $60 \%$ of the subsidies went to families with an income of not more than 1.6 Minimum Wage Units (about US\$ 366), while the remaining $40 \%$ went to families with an income between US\$ 366 and US\$ 1,053.

\footnotetext{
11 The Minimum Wage Unit is a unit of account established under Law No. 118/90. Its value, which is fixed by the competent authority, varies according to the variation of the current minimum monthly wage in the capital of the Republic for workers in various unskilled activities. In December 1996 one Minimum Wage Unit was equivalent to US\$ 229.
} 


\section{IV}

\section{Some lessons from the Latin American experience, and policy recommendations}

The two preceding sections make it clear, both in theory and practice, how radically Direct Housing Subsidies differ from traditional subsidies (such as housing loans at subsidized interest rates and subsidized dwelling prices) and how great their advantages are in terms of equity, efficacy of the fiscal effort and efficient operation of the financial system. Having made those aspects clear, we will now outline some of the conditions and characteristics that should exist in order for the use of DHS to give good results.

\section{Conditions needed for the successful application of direct housing subsidies}

In order to apply a DHS system successfully it is necessary to place these subsidies in their proper perspective, as part of housing policy and as a means of giving the lower-income population access to housing.

i) The aim of DHS, with the subsidiary intervention of the State, is to give the lower-income population access to the opportunities generated by a market sectoral development model. They are therefore totally divorced from a common myth lying at the basis of housing policies: that housing is a right. If the latter idea is accepted, then it would be necessary to identify exactly who should be obliged to provide housing, and it would naturally appear that this should be the obligation of the State. However, it would obviously be impossible for the State to comply with this assumed obligation, and any effort to do so would involve the implementation of projects by the State which would minimize the efforts made in this direction by families themselves: an approach which is diametrically opposed to that fostered by direct housing subsidies. What the State is really under the obligation to do is to guarantee that all families have equal access to the opportunities offered by the market, whatever their economic situation, but on condition that the families make an effort themselves, which would be suitably rewarded. ii) Direct housing subsidies should form part of a housing policy designed to do away with two mistaken approaches of the past: first, that the housing sector is a social sector, and second, that the housing problem can be solved by promoting massive housing construction projects. The housing sector undoubtedly does involve a problem with obvious social connotations, and the technical aspects are of considerable importance, but such approaches lead to the design of measures which prevent the sector from making use of economic resources in competition with other economic activities, since they scare off private investment, eliminate the possibilities of long-term finance and condemn the sector to a drastically reduced level of activity. DHS, in contrast, make possible a form of State intervention which creates spaces for the market economy and private investment, so that resources will flow into the sector.

iii) DHS should be an integral part of a comprehensive housing policy, not an isolated mechanism. This means, first, that the sectoral development model should be compatible with the general economic and social development model; second, that the housing policy should take account of the different needs and possibilities of all sectors of the population, in order to generate the right instruments (with their corresponding resources) for taking care of each of them; and third, that the housing policy should recognize the unavoidable need for State intervention but should at the same time promote private sector participation by creating conditions of profitability, competition and stability that will allow that sector to act as an executing agent, invest resources and assume risks.

iv) DHS can only make an effective contribution to reducing the housing deficit if saving and long-term mortgage loans for housing exist and are developed, since these subsidies are essentially a complementary and subsidiary means of gaining access to a dwelling. In order for them to be applied successfully, market conditions must prevail for financial operations relating to the housing sector, so that it is necessary to do away with all practices that 
lead to negative real interest rates on the housing finance markets. Interest rates are a key instrument for promoting financial saving for housing, making possible the recovery of long-term mortgage loans at their real value, and thus keeping alive financial intermediation for housing purposes.

v) Although DHS represent a special effort on the part of the State to give preferential attention to the lowest-income sectors, their application should not mean neglecting finance options for the higher income groups. The absence of such options would probably cause intermediate groups who do not have access to suitable opportunities to try to take advantage of the benefits designed for lower-income groups, crowding the latter out and leading to a deterioration in the targetting of fiscal resources. If groups with a certain amount of payment capacity find suitable options in the market, this will reduce the proportion of the population that need to be aided from the limited resources of the State.

vi) DHS are only one of the mechanisms required in order to take care of the housing needs of the lower-income population. Other complementary instruments are also required, such as the issue of legal proof of ownership for informal properties, in order to give informal dwellings commercial value and turn them into satisfactory collateral for mortgage loans, and the use of housing access mechanisms for informal sectors which are in a position to take on some long-term repayment obligations but cannot provide proof of a steady income.

vii) The benefits expected from DHS can materialize provided two basic conditions are fulfilled: sustainability of the necessary resources and credibility of the system. DHS require fiscal resources which are generally limited; consequently, once a programme of this type has been initiated it is important that it can be sustained in time in order to give stability to the demand for housing and allow private investment to develop its long-term capacity to provide dwellings in a competitive manner. It would be quite pointless to set in motion a DHS programme which creates expectations among potential beneficiaries and private investors but subsequently has to be deactivated because the resources have run out. At the same time, the system must win credibility: its operation must stimulate the functioning of the markets and must not involve any favouritism, so that it must use only procedures and criteria which are totally transparent and objective and hence leave no room for political manipulation.

\section{Desirable features of direct housing subsidies}

In the light of the experience of the different countries summarized above, DHS should have certain characteristics which will contribute to their efficacy and efficiency (duly adapted to the actual conditions of the area where they are to be applied, of course):

i) They should constitute a form of direct State aid designed to create purchasing power to acquire a housing solution: that is to say, they aid the demand for housing, not supply. This feature means that the subsidiary intervention of the State will be suitably targetted and not indiscriminate, thus making it possible to effectively aid the target population. It will also make it possible to attract private enterprise into the housing sector rather than driving it out, since it will not introduce price distortions into the real estate and housing finance markets.

ii) They should be non-repayable, thus recognizing that without such subsidies low-income families will not be able to acquire a dwelling solely on the basis of the opportunities provided by the market. Their non-repayable nature also saves the State the administrative costs inherent in any efforts to recover outlays. In actual fact, these outlays will largely return to the State through the greater tax revenue deriving from the direct and indirect impact of increased activity in the housing sector.

iii) They should be granted only once in the lifetime of families, which should not already be owners of a dwelling. DHS will thus be an expression of the supportive aid of the State and society for families in the poorest sectors of the population who are willing to make an effort, within their possibilities, to obtain a housing solution.

iv) They should be a complement to, and not a replacement for, the families' possibilities of saving and indebtedness, especially in the case of the lowest-income sectors. The efficacy of the subsidies will depend to a large extent on the existence and expansion of saving and mortgage loans. As some of the case studies show, the possibility of obtaining a mortgage loan to make up the cost of the dwelling has often been a decisive factor in enabling beneficiaries of the subsidy to make effective use of it. The case of Costa Rica shows the desirability of DHS being linked with a mortgage loan, whereas the case of Colombia highlights the disadvantages of a situation where the beneficiaries of subsidies cannot gain 
effective access to a mortgage loan, so that the effective use made of the subsidies approved is relatively low. The rediscounting of mortgages may be useful for helping the State to promote greater participation of private financial institutions in the granting of long-term mortgage loans to DHS beneficiaries, by giving faster rotation and greater liquidity to the resources loaned. One of the main problems that needs to be solved in many countries is the limited participation of the private financial sector in the provision of small housing loans.

v) They should be based on the use of clearly measurable public resources, since among other advantages this helps to give a clear perception of the efforts being made by the State in providing aid targetted on the poorest sectors. It is highly desirable that DHS should be financed from a budget item which does not make any distinctions as regards the source of the funds: in this way, the sustainability of the system will depend essentially on the soundness of the public finances of the country in question. Furthermore, their dependence on the public budget will introduce an important incentive for the efficient management of the outlays in question, since each year this will be a key element in the analysis of how the use made of these resources compares with public expenditure in other sectors.

vi) The amounts of the subsidies must be made clear to those receiving them, so as to create a full awareness among beneficiaries of the aid they are receiving from the State: something which is not always possible when State aid takes the form of hidden subsidies. Therefore, subsidies should be given in the form of actual funds (or their equivalent, such as the certificates used in some countries), thus promoting the free choice of a dwelling by the beneficiary families. When the aim is to aid the very poorest sectors, and the State is compelled to actually build dwellings for them, or when the subsidy is practically equivalent to the price of the dwelling, the State should invite tenders for the private sector to build the dwellings directly. The limited response of the private sector to the stimulus of DHS in terms of providing low-cost dwellings is another problem which needs to be solved in some countries.

vii) The subsidies should be of different amounts, in line with an established scale, as a function of the applicant's income and the cost of the dwelling, with priority being given to progressiveness (i.e., the lower the applicant's income and the lower the cost of the dwelling, the higher the sub- sidy), so that State aid to the poorest sectors is not only proportionately greater compared with the cost of the housing solution but is also greater in absolute terms. It is also desirable that the values of the subsidies should be expressed in units of account which determine their variation over time, especially in line with inflation, as this would make their discretionary readjustment unnecessary and protect their real value against inflation. In practice, it may prove to be somewhat complex and costly to target State aid properly on the poorest groups. Experience shows that the use of income as a key variable for determining this objective can involve considerable margins of error, so it would be desirable to take into account other items of reference, as a number of countries have done. Firstly -especially in systems designed to provide initial housing solutions rather than finished dwellings for the lowest income strata- a more objective targetting criterion would be the current shortcomings in the dwelling that it is desired to improve with the subsidy. Secondly, scales could be established which link such variables as income, cost of the dwelling, maximum subsidy and minimum prior saving, and limits could be established for the standards of dwellings that applicants can aspire to, according to their economic possibilities: this would also help to promote self-discrimination among the applicants, as it is unlikely that a family would apply for a lower-cost dwelling simply in order to obtain a larger subsidy if its economic possibilities were such as to permit it to obtain a more expensive dwelling (this hypothesis is strengthened by the very low level of housing mobility in the countries of the region). Thirdly, prior saving -as an objective means of measuring the effort made by families to attain a subsidy and a housing solution- may be given decisive weight in targetting (as in the case of Chile), while giving due weight to the fact that the lowest-income families have less capacity to save and thus placing them on an equal footing for competing with higher-income families (as in the case of Uruguay).

viii) They should be administered through transparent procedures which are fully known and understood by applicants, beneficiaries and the public at large. The criteria for selecting the beneficiaries should be objective: they should be based on measurable and impersonal factors (as for example through a points system), and should be free from all kinds of discretionality. The credibility of the DHS system, and hence its permanence in time and its effectiveness for dealing with the needs of the poorest sectors, 
will directly depend on the transparency of the procedures and the objectivity of the criteria for selecting the beneficiaries, which should rule out all possibility of political favouritism or influences which will discredit the system and endanger its survival. The ongoing improvement of this transparency and objectivity should be a constant part of the efforts to secure better targetting of DHS; the norms applied and the results obtained should be evaluated periodically and, if necessary, suitable changes should be made.

ix) In awarding the subsidies, emphasis should be placed on the requirement for methodical prior saving. Such saving is not only a reflection of the effort made by families to attain a housing solution but should also be an objective criterion in the allocation of subsidies (points should be given for the amount and length of prior saving, for example, among other factors). This will encourage families to be active participants in their search for a housing solution and not mere passive recipients of State handouts. In the cases studied, all the countries except one consider prior saving or some expression of family effort to be an essential requirement for seeking and obtaining a subsidy. In order to prevent the prior saving requirement from prejudicing the poorest families, there are procedures for putting them on an equal footing with higher-income families. Furthermore, the prior saving of lower-income applicants can also be expressed in kind (building plots, for example). Indeed, El Salvador has adopted an even broader interpretation of "prior saving": under the DHS system applied there, credit is given for the sacrifices involved in a poor family's willingness to leave a marginal area where they are living and move to a more orderly settlement where, however, they will have to rebuild their economic relations. Another substantial argument for making prior saving a requisite for obtaining a subsidy is that it strongly encourages an increase in the amount of savings channelled through the financial system.

$\mathrm{x})$ It is necessary to define whether the DHS is to be used for acquiring a finished dwelling, obtaining an initial (expandable) housing solution, or improving an existing dwelling, and whether there should be a process of gradual improvement of the dwelling as a function of the economic possibilities of the beneficiaries. A key element in taking the final decision will be the source and amount of the resources available for the provision of subsidies. At all events, when the subsidy is to be used in the acquisition of finished dwellings it is important that the proportion of the total price of the dwelling covered by it should be sufficiently large to ensure that the subsidies approved are actually used. The provision of initial housing solutions that can subsequently be improved and expanded may also be a very useful approach, especially for the lowest-income sectors: as well as requiring fewer resources, the standard of these dwellings will be in keeping with the beneficiaries' real economic possibilities and priorities, thus avoiding later difficulties in maintaining the dwellings and continuing with their gradual improvement.

It will also be important to define whether DHS can only be used for the acquisition of new finished dwellings or whether they can also be used to buy a second-hand dwelling. If the latter is possible, this can substantially help in the formation of a secondary housing market for the low-income groups, making it easier for families who already own a dwelling and whose income has increased to sell their used dwelling in order to acquire another one which is better and more expensive. Since a very high percentage of the total housing stock of a country are used dwellings, authorization to use the subsidies to acquire either new or used dwellings would allow the lower-income sectors to begin their process of obtaining their own dwelling by purchasing low-cost used housing. This approach has recently been introduced in Chile, where the subsidies were previously for the acquisition of new finished dwellings.

Another important lesson to be drawn from the case studies is the desirability of encouraging collective, and not only individual, applications for DHS. At least for the lowest-income population, this would seem to be useful for two reasons: on the one hand, it promotes the participation of bodies that further the organization of the demand for housing and thus improve the possibilities and capabilities of the population involved in the process of applying for subsidies, and on the other hand, it brings about more effective utilization of the subsidies, since the process of seeking a housing solution through these benefits and/or mortgage loans needed to make up the cost of the dwelling is strengthened by specialized, organized technical support which helps to put the applicants for dwellings or housing credit on a more equal footing with the respective suppliers.

(Original: Spanish) 


\section{Bibliography}

Arroyo, E. (1995): La focalización del gasto público en vivienda como instrumento de desarrollo económico y social, Inter-American Housing Union, Anales de la XXXIII Conferencia Interamericana para la Vivienda, Lima.

Bertrand, F. (1995): Subsidios directos a la demanda por vivienda: el caso del Programa de Contribuciones Habitacionales en El Salvador, in G. M. Gonzales Arrieta (ed.), Financiamiento de la vivienda para grupos de bajos ingresos: experiencias latinoamericanas, Lima, Inter-American Housing Union.

Castañeda, T. (1990): Para combatir la pobreza. Política social y descentralización en Chile durante los '80, Santiago, Chile, Centre for Public Studies (CEP).

Domínguez, V. (1994a): El ahorro previo para adquirir viviendas, Santiago, Chile, mimeo.

- (1994b): Conjunto de principios para definir el marco conceptual de los subsidios habitacionales en el Ecuador, consultant's report to the United States Agency for International Development (USAID), Regional Housing and Urban Development Office (RHUDO), Quito, mimeo.

ECLAC (Economic Commission for Latin America and the Caribbean) (1995): Situación de la vivienda en América Latina y el Caribe, La producción de la vivienda en América Latina y el Caribe, Santiago, Chile.

(1996): Producción de la vivienda en América Latina y el Caribe: áreas de interés para una política habitacional innovativa, Santiago, Chile, Joint ECLAC/UNCHS Human Settlements Unit.

Gonzales Arrieta, G. (1995): Housing policy and financing in Latin America: a retrospective analysis and an alternative model, Housing Finance International, vol. IX, No. 3, Chicago, Illinois, International Union of Housing Finance Institutions (IUHFI), March.

Gonzales Arrieta, G. (ed.) (1995): Financiamiento de la vivienda para grupos de bajos ingresos: experiencias latinoamericanas, Lima, Inter-American Housing Union.

Hermosilla, E. (1995): La vivienda y la economía social de mercado: la experiencia de Chile, Inter-American Housing Union, Anales de la XXXIII Conferencia Interamericana para la Vivienda, Lima.
INURBE (Instituto Nacional de Vivienda de Interés Social y Reforma Urbana) (1995): Política de vivienda social urbana, Política de vivienda, documento CONPES No. 2729, Santafé de Bogotá.

Mayo, S. and S. Angel (1993): Housing: enabling markets to work with technical supplements, World Bank policy paper, Washington, D.C., World Bank.

Melo, P. (1995): Subsidios directos a la demanda por vivienda: el caso del Sistema de Subsidio Habitacional en Chile, in G. M. Gonzales Arrieta (ed.), Financiamiento de la vivienda para grupos de bajos ingresos: experiencias latinoamericanas, Lima, Inter-American Housing Union.

Monge, G. (1995): Subsidios directos a la demanda por vivienda: el caso del Bono Familiar de Vivienda en Costa Rica, in G. M. Gonzales Arrieta (ed.), Financiamiento de la vivienda para grupos de bajos ingresos: experiencias latinoamericanas, Lima, Inter-American Housing Union.

Pees, E. (1996): Políticas habitacionales: la experiencia uruguaya, Banco Nacional Hipotecario, 1er Simposio: Modalidades de financiamiento de vivienda para sectores de medianos y bajos recursos, Panama City.

Romay, M. (1995): Subsidios directos a la demanda por vivienda: el caso del Sistema Integrado de Acceso a la Vivienda en el Uruguay, in G. M. Gonzales Arrieta (ed.), Financiamiento de la vivienda para grupos de bajos ingresos: experiencias latinoamericanas, Lima, Inter-American Housing Union.

Salazar, S. (1995): Subsidios directos a la demanda por vivienda: el caso del Subsidio Familiar de Vivienda en Colombia, in G. M. Gonzales Arrieta (ed.), Financiamiento de la vivienda para grupos de bajos ingresos: experiencias latinoamericanas, Lima, Inter-American Housing Union.

US-AID (United States Agency for International Development) (1987): Cómo fomentar la iniciativa privada. Nuevos papeles de los sectores público y privado en la producción de vivienda de bajo costo en países en desarrollo, Washington, D.C., Regional Housing and Urban Development Office.

Zawadzki, C. (1993): Nuevos modelos de financiamiento de vivienda en América Latina, Inter-American Housing Union, Anales de la XXXI Conferencia Interamericana para la Vivienda, Lima. 